\title{
Specifikace znalecké činnosti v oboru koroze a ochrana proti korozi
}

\section{Specification of Experts' Work in the Field of Corrosion and Corrosion Protection}

\author{
Kateřina Kreislová*, Eva Kalabisová, Hana Geiplová
}

SVÚOM s.r.o., Praha

\begin{abstract}
Abstrakt
Obor koroze a ochrana proti korozi je relativně široký a týká se celé řady národohospodářských odvětví, v nichž se uplatňují kovové materiály. Odborníci musí mít dobré vzdělání a znalosti jak z oboru chemie, tak i stavebnictví a strojírenství, kam tato problematika přesahuje. Př́spěvek dokumentuje několik př́ikladů z praxe, kde nedostatečná odbornost znalců vedla $\mathrm{k}$ nesprávným závěrům.
\end{abstract}

Klíčová slova: koroze, ochrana proti korozi, chemie, stavebnictví, strojírenství.

\section{1. ÚVOD}

SVÚOM s.r.o. je výzkumná organizace zajišt'ující výzkum, vývoj, konzultace, zkoušky, inspekce, znalecké posudky, včetně environmentálních posudků, a další činnosti v rámci svých výzkumných projektů a v souladu s požadavky uživatelů z praxe. SVÚOM s.r.o. byla založena v r. 1999 a pokračuje v činnosti Státního výzkumného ústavu ochrany materiálu (1952-1994). Znaleckou činnost vykonává nepřetržitě od počátku 70. let minulého století a je jediným znaleckým ústavem zapsaným v seznamu znaleckých ústavů Ministerstva spravedlnosti pro obor koroze a ochrana proti korozi.

Pro své dlouhodobé tematicky důsledné a hluboké zaměření činnosti na obor koroze a protikorozní ochrana byl SVUUOM žádán Úřadem pro normalizaci a měření o spolupráci při tvorbě oborových národních a mezinárodních standardů. Tato spolupráce trvá desítky let a nyní je SVÚOM centrem technické normalizace ČAS (dříve UNMZ) pro oblast koroze a protikorozní ochrany. Odborníci SVÚOM jsou členy mezinárodních a národních technických komisí normalizačních organizací (ISO, CEN) a aktivně se podílí

\begin{abstract}
Field of corrosion and corrosion protection is relatively wide and it is related to many different sectors, in which metallic materials are used. Experts must have adequate education and knowledge from chemistry and also civil engineering and machinery to which the issues overlap. The paper documents some examples from praxis where nonsufficient experts' speciality results into wrong conclusions.
\end{abstract}

Keywords: corrosion, corrosion protection, chemistry, civil engineering, machinery.

na vytváření technických norem v oblasti koroze a ochrany proti korozi. Tyto zkušenosti bezpochyby přispívají ke zvýšení kvality znalecké činnosti v tomto oboru.

\section{OBOR KOROZE A PROTIKOROZNÍ OCHRANA}

Obor koroze a protikorozní ochrany je zaměřen na řešení korozní problematiky všude tam, kde jsou kovy využívány jako konstrukční materiály. Je známo, že ve vyspělých zemích se celkové roční korozní ztráty pohybují v rozsahu 3-5\% HDP, přičemž z toho 1-2\% HDP (tj. desítky miliard Kč) představují ztráty, kterým lze úspěšně čelit [1-4]. Problematika koroze a ochrany proti korozi aplikací různých postupů a procesů se týká prakticky všech výrobků zhotovených z kovových materiálů od špendlíků a jehel (např. spolupráce SVÚOM s fy Kooh-i-Noor, Precioza, apod.) přes kloubní náhrady ve zdravotnictví či výrobní linky v různých průmyslových závodech až po výztuže v betonu a mostní či jiné rozměrné konstrukce (např. spolupráce SVÚOM s fy Metrostav, ČEPS, ČEZ, Česká rafinerská, Lovochemie, apod.). 

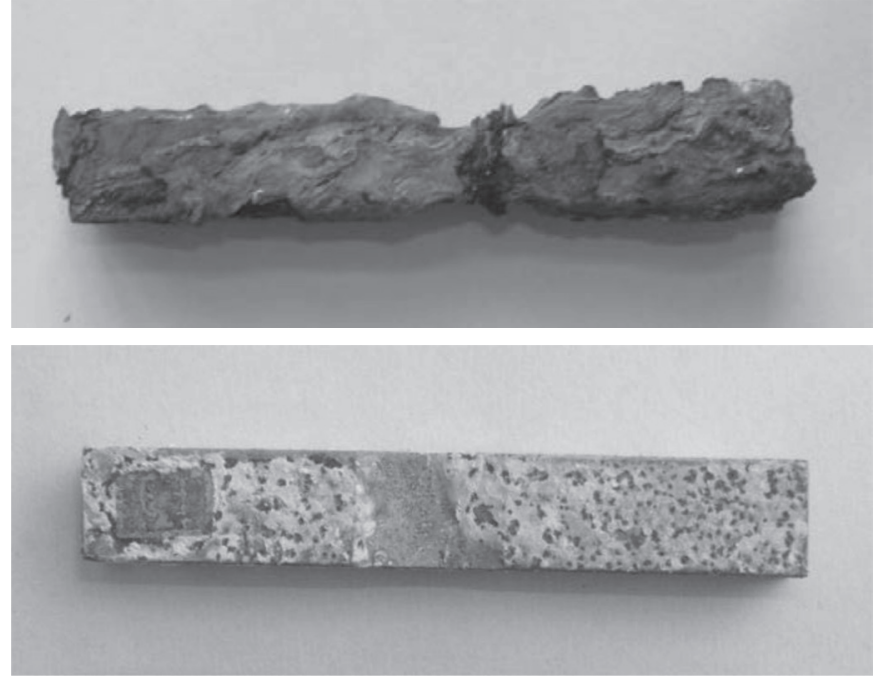

Obr. 1 Přiklad korozniho napadení uhlikové oceli a hlinikové slitiny [8].

Fig. 1 Example of corrosion attack of carbon steel and aluminium alloy [8].

Většina korozních procesů probíhá elektrochemickým mechanismem, a proto je velmi důležitá kvalita vzdělání pro tuto specifickou oblast $v$ oboru chemie. Je nutné porozumět interakci mezi materiály, především povrchy materiálů, a jejich prostředím, protože korozní proces probíhá ve většině prípadů na rozhraní těchto systémů. Do korozního děje se zapojují chemické, fyzikální, elektrochemické a další vlivy, které mají dynamický průběh, mění se s řadou vnější parametrů (teplota, vlhkost, rychlost proudění, koncentrace složek, atd.) a projevují se odlišně u různých kovových materiálů či jejich kombinací, popr. i jejich povrchových úprav [5-7].

Identifikovat jednotlivé formy korozního napadení a posoudit jejich závažnost $\mathrm{z}$ hlediska zbytkové životnosti, bezpečnosti provozu, atd. je jedním $z$ důležitých výsledků odborných pracovníků - viz obr. 1 a 2, které dokumentují různé formy korozního napadení různých kovových konstrukčních materiálů i z hlediska závažnosti. V př́padě hliníkové slitiny je korozní napadení závažnější než u uhlíkové oceli, protože hliníkové slitiny korodují lokálními formami korozního napadení, které závažně ovlivňují vnitřní strukturu materiálu.

\section{ZNALECKÁ ČINNOST V OBORU}

\section{1 Činnost SVÚOM s.r.o.}

SVÚOM s.r.o. je zapsán do seznamu znaleckých ústavů ministerstva spravedlnosti, oddíl II - obor koroze a protikorozní ochrana. Činnost je prováděna na základě zákona č. 36/1967 sb., o znalcích a tlumočnících a vyhlášky č. 37/1967 Sb.

Někteří zaměstnanci SVÚOM s.r.o. jsou zároveň zapsanými znalci pro daný obor. Trvale se vzdělávají jak v oboru koroze a ochrana proti korozi, tak i v obecné problematice znalectví. Významnou výhodou pro výkon znalecké činnosti je jejich aktivita ve výzkumné a publikační činnosti, která je k nahlédnutí ve veřejně př́stupných registrech a databázích.

Od r. 2000 vypracoval SVÚOM s.r.o. již přes 250 znaleckých posudků pro průmyslové organizace, soukromé osoby, ale i orgány státní správy (soudy, policie, atd.).

\subsection{Jiné znalecké ústavy a znalci}

Na www.justice.cz není pro obor koroze a protikorozní ochrana v seznamu znaleckých ústavů, oddíl I, zapsána žádná univerzita či veřejná výzkumná instituce, atd. V oddílu II je zapsán pouze SVÚOM s.r.o.

V Evidenci znalců a tlumočníků jsou sice zapsáni znalci ze SVÚOM s.r.o., ale jsou však obtížně vyhledatelní, protože na obor koroze a protikorozní ochrana není v seznamu jednotlivců pamatováno a figurují v jiných oborech, napr. „Technické obory - různé“. Zájemce o vypracování posudku v oboru koroze a protikorozní ochrana má pouze omezené možnosti vyhledání těchto znalců pouze prostřednictvím popisu činnosti uváděné u každého znalce. Takové vyhledávání znalců v Seznamu však může být často neúspěšné.

Lze odhadnout, že v současné době se aktivní znaleckou činností v oboru koroze a protikorozní ochrana zabývá maximálně 15 osob.

Ovšem v oboru povrchové úpravy jsou zahrnuty i takové oblasti jako:

- umění výtvarné: renovační a restaurátorské práce, umělecké truhlářství, řezby a povrchové úpravy, a

- stavební odvětví různá: hydroizolace, izolace, povrchové úpravy staveb, jejich vady a povrchy.

Obory, ze kterých se znalci vyjadřují k problematice koroze a ochrany proti korozi (povrchové úpravy), jsou: chemická odvětví

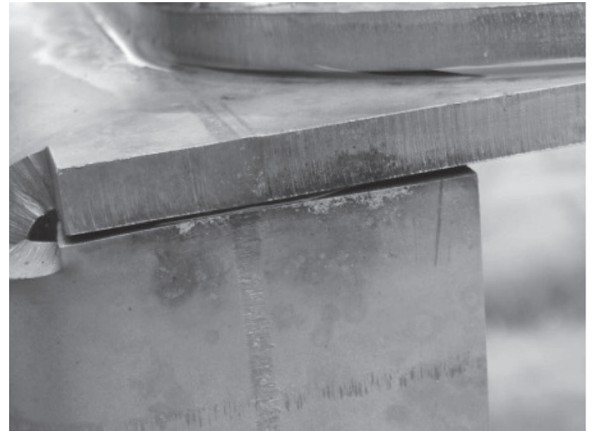

korozni napadení identifikované uživatelem - zanedbatelné riziko

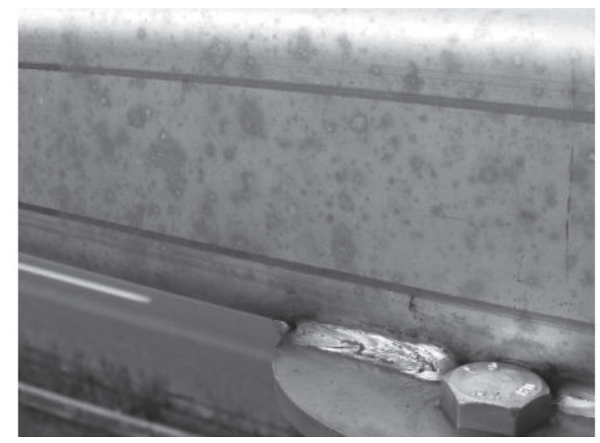

důlkové korozní napadení - významné riziko

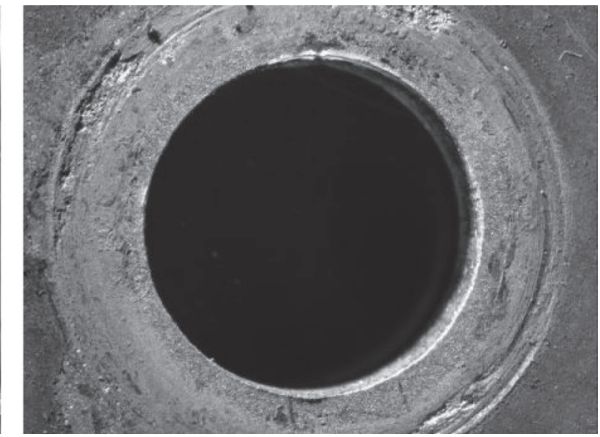

štěrbinové a důlkové korozní napadení pod šroubovým spojem - kritické korozni napadeni - identifikace odbornikem

Obr. 2 Různé formy korozniho napadeni na jedné konstrukci z korozivzdorné oceli [8].

Fig. 2 Different type of corrosion attack on one structure from stainelss steel [8]. 
různá, chemie všeobecná, strojírenství všeobecné, strojírenství těžké, stavební odvětví různá, stavby průmyslové, obytné, stavební materiál, aj. Z toho je zřejmé, že v některých př́ípadech nemají potřebné vzdělání v oboru chemie.

\subsection{Příklady ze znalecké praxe}

Během vypracovávání výše uvedeného počtu znaleckých posudků se znalci SVÚOM s.r.o. setkali s řadou nedostatečných znalostí „znalcư“ [8], především:

- terminologie - pro obor koroze a ochrana proti korozi existuje norma ČSN EN ISO 8044 Koroze kovu a slitin Základni termíny a definice a dále řada terminologických norem pro jednotlivé typy povrchových úprav; přesto zde existuje lidová tvořivost v popisu jednotlivých stavů materiálů, jak se komu zlíbí;

- neznalost technických norem pro posuzování kvalitativních i kvantitativních parametrů korozního napadení nebo provedených povrchových úprav - použití neplatných nebo nerelevantních technických norem, záměna norem pro různé metody měřní, vlastnosti, atd.;

- nevhodné postupy hodnocení, nedostatečné vybavení pro hodnocení (např. měření korozních úbytků mostní konstrukce mikrošroubem, analýza chemického složení kovového materiálu mobilním př́istrojem provozovaným přidruženou výrobou zemědělského družstva);

- nesprávná interpretace zjištěných výsledků - v mnoha př́padech znalci a/nebo znalecké ústavy provedenou i kvalifikované měření, ale interpretují je pouze částečně nebo z pohledu jejich odbornosti, nikoliv odbornosti $\mathrm{v}$ oboru koroze a ochrana proti korozi.

\section{ZÁVĚR}

V příspěvku jsme se pokusili stručně shrnout, jaké jsou problémy ve znalecké činnosti ve velmi specifickém oboru koroze a ochrana proti korozi. O kvalitě znalostí nesvědčí ani doba existence některých organizací, ani obsáhlá literatura $v$ jejich knihovně, jak bylo vysvětlováno. Především s ohledem na připravovaný nový zákon je třeba zvýšit kvalitu znalců i v tomto oboru.

\section{LITERATURA}

[1] KOCH, G. H., BRONGERS, M. P. H., THOMPSON, N. G., VIRMANI, Y. P., PAYER, J. H. Corrosion Costs and Preventive Strategies in the United States, Report FHWA-RD-01-156, NACE.

[2] A Survey of the Cost of Corrosion to Japan, Japan Society of Corrosion Engineering and Japan Association of Corrosion Control, Chairman G. Okamoto, 1977.

[3] CHERRY, B. W., SKERRY, B. S. Corrosion in Australia The Report of the Australian National Centre for Corrosion Prevention and Control Feasibility Study, 1983.

[4] SOTAQUIRA, R. et al. A System Approach for Estimating Corrosion Incidence to the Economy of a Nation, 1994 International System Dynamics Conference, 1994.

[5] Corrosion, Vol 13, ASM Handbook, ASM International, 1987.

[6] Corrosion and Corrosion Protection Handbook, $2^{\text {nd }}$ ed., P. A. Schweitzer, Ed., Marcel Dekker, 1989.

[7] PAYER, J. H. et al. Mater. Perform., Vol 19 (No. 9), June 1980, s. $19-20$.

[8] Archív SVƯOM s.r.o.

\section{Správná citace:}

KREISLOVÁ, K., KALABISOVÁ, E., GEIPLOVÁ, H. Specifikace znalecké činnosti v oboru koroze a ochrana proti korozi. Soudní inženýrství, 2019, 30(1), 25-27. DOI: http://dx.doi.org./10.13164/SI.2019.1.25. ISSN 1211-443X. 